MAJA MOROCH (D) orcid.org/0000-0002-4983-3682

DOROTA SUWALSKA-BARANCEWICZ (D) orcid/org/0000-0001-6495-9796

Zakład Psychologii Społecznej

Wydział Psychologii

Uniwersytet Kazimierza Wielkiego w Bydgoszczy

Department of Social Psychology

Faculty of Psychology, Kazimierz Wielki University in Bydgoszcz

e-mail: dsbarancewicz@ukw.edu.pl

\title{
Przywiązanie pacjentów z rozpoznaniem schizofrenii a jakość ich relacji z rodzicami - mediacyjna rola prężności
}

\section{The Importance of Resilience in Patients Suffering from Schizophrenia and the Quality of Their Attachment and Relationship with Their Parents}

\begin{abstract}
The aim of the study was to analyze whether the individual dimensions of resilience and attachment are related to the quality of relationships with parents of people with schizophrenia and the indication of mediators determining the quality of these relationships. 50 participants took part in the study. The average age of the respondents was 49 years. Measurements of independent variables were made using Experiences in Close Relationships Revised by Chris Fraley, Kelly Brennan, and Neils Waller, in the Polish adaptation by Cezary Wiśniewski (2011); and Lifespan Individual Resilience Scale (pl) (LIRS (pl)) in the Polish adaptation of Malina, Pooley, and Harms (2016). The quality of the relationship was measured using The Quality Relationship Inventory in the Polish adaptation of Dorota Suwalska-Barancewicz, Paweł Izdebski, and Hanna Liberska (2015). The results confirmed the existence of significant, strong relationship between discrete resilience dimensions and the quality of relationship with parents. The research also confirmed that there is a significant relationship between the dimensions of resilience and the dimensions of attachment and between the dimensions of attachment and the quality of relationships with parents. It also turned out that the level of resilience is an important mediator between attachment and perceived support from parents.
\end{abstract}

Keywords: resilience, attachment style, quality of relationship, schizophrenia

Słowa kluczowe: prężność, jakość relacji, styl przywiązania, schizofrenia

\section{WPROWADZENIE}

Bliskie relacje i więź z drugim człowiekiem stanowią element poczucia szczęścia i dobrostanu psychicznego. Współdecydują one o ludzkim zdrowiu, zwiększając wydajność układu odpornościowego i redukując poziom hormo- nów stresu. Pozwalają również poradzić sobie w obliczu zagrożenia śmiercią i stratą ukochanej osoby (Uchino, Cacioppo, Kiecold-Glazer, 1996; Czapiński, Panek, 2007; Perlman, 2007). Trwanie w bliskiej relacji stwarza okazję do realizacji wielu ludzkich potrzeb: bezpieczeństwa, przynależności, miłości, afiliacji, kontaktu, 
szacunku, uznania oraz wielu innych, do których realizacji niezbędna jest obecność drugiego człowieka (Ryś, 1999). Od zaspokojenia tych potrzeb zależy nie tylko powodzenie relacji, ale również jakość życia człowieka (Hazan, Shaver, 1987; Doroszewicz, 2008).

Problematyka bliskości jest szczególnie istotna $\mathrm{w}$ odniesieniu do rodzin, w których członkowie zmagają się z problemami zdrowotnymi. Choroba staje się problemem, nie tylko pacjenta, ale i całej rodziny, zakłócając dotychczasową realizację celów i zadań życiowych. Zmaganie się z chorobą, zwłaszcza przewlekłą, prowadzi do zmian w systemie rodzinnym, wymaga przeformułowania sposobów walki z nią oraz wiąże się z długim procesem adaptacji przy dużym udziale silnego stresu (Heszen, Sęk, 2007; Świętochowski, 2014). Atmosfera rodzinna ma niebagatelny wpływ na częstotliwość nawrotów choroby czy też stopień przystosowania się do nowych warunków, co jest szczególnie istotne wśród rodzin, w których pojawiła się choroba psychiczna (Brown i in., 1962; de Barbaro, Ostoja-Zawadzka, Cechnicki, 2005; por. też Świętochowski, 2014).

Wystąpienie schizofrenii w rodzinie odciska piętno na życiu zarówno osoby chorej, jak i jej bliskich, a jej diagnoza wiąże się $\mathrm{z}$ różnorodnymi reakcjami emocjonalnymi członków rodziny - najczęściej pojawiają się szok, rozpacz, poczucie bezradności, niedowierzanie, zaprzeczanie, smutek czy też brak akceptacji choroby (Sęk, Steuden, 2016). Badacze zjawiska zwracają uwagę na obciążenie rodziny, które może być analizowane w odniesieniu do wymagań związanych z chorobą, oceną poznawczą, sposobami radzenia sobie oraz emocjonalnym stosunkiem do podejmowanych zadań (de Barbaro, 1999). Badania pokazują, że subiektywna ocena ciężkości obciążenia jest bardzo zróżnicowana - dla jednych rodzin obecność osoby z rozpoznaniem schizofrenii stanowi ciężar, dla innych jest okazją do mobilizacji sił i zmiany funkcjonowania, a także źródłem sensu życia (Sęk, Steuden, 2016). Uważa się, że schizofrenia może przyczyniać się do przewlekłego upośledzenia funkcjonowania osoby. Badania wskazują, że połowa pacjentów w europejskich szpitalach psychiatrycznych choruje na schizo- frenię (Wright, 2008). Ryzyko zachorowania na tę chorobę w ciągu życia wynosi około $1 \%$. Najczęściej jest ona rozpoznawana u ludzi między 15. a 45. rokiem życia (Alanen, 2000). Charakterystyczne dla obrazu klinicznego schizofrenii jest to, że pacjenci z jej diagnozą doświadczają wysokiego poziomu lęku, który izoluje ich od świata, czyni cierpiącymi i samotnymi. Podkreśla się, że w człowieku chorym psychicznie nie można widzieć tylko choroby, gdyż tak redukcjonistyczne podejście sprawia, że nie dostrzega się w nim ogromu cierpienia i pozbawia się go godności (Kępiński, 1992; Sęk, Steuden, 2016).

Prawdopodobnie nie ma prostego związku przyczynowo-skutkowego między zaburzeniami funkcjonowania rodziny a zaburzeniami psychicznymi u pacjenta, jednak specyficzne funkcjonowanie rodziny, które znajduje odzwierciedlenie w różnych formach bliskości uznawanych za patologiczne, może być jednym z czynników wpływających na powstawanie i trwanie lub przebieg zaburzenia (Chrząstowski, 2012). Tym samym funkcjonowanie rodziny może być zarówno czynnikiem chroniącym, jak i czynnikiem ryzyka w powstawaniu schizofrenii i zaburzeń z jej spektrum (Bloch i in., 1994). Literatura przedmiotu wskazuje, że przyczyną choroby może być nadmierna bliskość matki wobec dziecka, nadmierne zaangażowanie w życie dzieci, ale także mało troskliwa opieka ze strony rodziców, której towarzyszy kontrolowanie dziecka (Parker, 1990; Chrząstowski, Zagdańska, 2008; Chrząstowski, 2012). Nadmierna bliskość czy też nadopiekuńczość matki względem dziecka wyraża się w tworzeniu relacji symbiotycznych, w których zaburzone są procesy wiązania i odsuwania - nasilenie wiązania (opóźniającego separację od rodziców) może się przyczynić do rozwoju schizofrenii u dziecka (Stierlin i in., 1999). Inni badacze upatrują roli tych czynników w późniejszych nawrotach schizofrenii (Favaretto, Torresani, Zimmermann, 2001). Przypuszcza się również, że zbyt wczesna separacja od rodziców jest czynnikiem ryzyka rozwoju schizofrenii u dorosłych osób. Teza ta wymaga jednak dalszego potwierdzenia w badaniach (Chrząstowski, 2012). Wskazują one również na to, że osoby z diagnozą schizofrenii odczuwają zarówno lęk przed samotnością, jak 
i lęk przed zbytnią bliskością, objawiający się postawą dążeniowo-unikową (Chudzikiewicz, 2013), co może modyfikować charakter relacji osób z rozpoznaniem schizofrenii z członkami rodziny.

Niewątpliwie dla jakości relacji rodzinnych duże znaczenie ma przywiązanie kształtowane od najmłodszych lat. Bezpieczna baza (Ainsworth $\mathrm{i}$ in., 1978) i wsparcie $z$ niej płynące mogą regulować procesy tworzenia związków interpersonalnych (Waters, Cummings, 2000; Bowlby, 2007). Badania wskazują, że osoby z rozpoznaniem schizofrenii mogą przejawiać cechy bezpiecznego stylu przywiązania, charakteryzującego się brakiem tendencji do unikania bliskości, a także odczuwaniem wysokiego poziomu satysfakcji z relacji. Są przeświadczone o dostępności bliskiej osoby w trudnych, ważnych i kryzysowych sytuacjach, nie wzbraniają się przed odkrywaniem się czy ,zacieśnianiem granic". Cechują się większą ugodowością, co przejawia się pozytywnym stosunkiem do otoczenia, ustępliwością oraz większą wrażliwością. Zwracają uwagę na potrzeby bliskiej osoby i starają się podtrzymywać pozytywną relację (Uznańska, Czabała, 2004). Ich komunikacja oparta jest na wzajemnym zaufaniu, otwartości, przeświadczeniu, że jest się chętnie wysłuchiwanym i życzliwie wspieranym. Jest to podstawa budowania i utrzymywania pozytywnej relacji z drugim człowiekiem (Chudzikiewicz, 2013).

$\mathrm{W}$ niektórych rodzinach osób z diagnozą schizofrenii można obserwować odsuwanie się rodziców od dziecka, wrogość wobec niego i krytycyzm. Badania wykazały, że im bardziej rodzice czują się obciążeni koniecznością opieki nad dzieckiem, tym silniej je odsuwają. Okazało się również, że im w większym stopniu rodzice przypisują dziecku cechy, które mają świadczyć o jego niesamodzielności i szaleństwie, tym bardziej zwiększa się prawdopodobieństwo odsuwania dziecka, co wiąże się z niesatysfakcjonującą jakością relacji (Chrząstowski, 2012). Może to prowadzić do pozabezpiecznego przywiązania, w którego wyniku jednostki mają tendencję do negatywnego oceniania potencjalnych źródeł wsparcia i mniejszą skłonność jego udzielania bliskim osobom. Z kolei ufność przywiązaniowa zwią- zana jest z wyższym postrzeganiem wsparcia i odpowiednim reagowaniem na potrzeby bliskiej osoby (Florian, Mikulincer, Bucholtz, 1995; Mikulincer, Florian, 1997; Mikulincer, Shaver, 2007).

Wobec licznych trudności, jakich doświadcza rodzina, u której członka rozpoznano schizofrenię, ważna dla jakości funkcjonowania w każdym obszarze jest umiejętność radzenia sobie z trudnościami, a także szybkiego odzyskiwania równowagi w sytuacji kryzysu. Jednym z czynników chroniących i pomagających w radzeniu sobie jest prężność. Odnosi się ona do procesu skutecznego przezwyciężania niesprzyjających zdarzeń pod wpływem transakcji jednostki i systemu, w którego ramach funkcjonuje. W odniesieniu do rodzin $\mathrm{z}$ rozpoznaniem schizofrenii może to dotyczyć konieczności określenia na nowo celów i zadań rodziny, redefiniowania ról rodzinnych i sprecyzowania w nich miejsca dla osoby chorej (Sęk, Steuden, 2016). Prężność wiązana jest także ze zdolnością do pozyskiwania i budowania zasobów sprzyjających zdrowiu oraz możliwością zabezpieczenia tych zasobów przez środowisko rodzinne i otoczenie społeczne w kontekście doświadczania stresu, trudności i kryzysów (Charney, 2004; Connor, 2006; Hjemdal, 2007; Pooley, Cohen, Connor, 2010).

Prężność psychiczna w połączeniu z bezpiecznym stylem przywiązania wpływają na prawidłowe funkcjonowanie jednostki. Istotne okazują się tutaj badania Normana Garmezy'ego, który zaobserwował, że część dzieci dorastających w rodzinach z osobą chorą na schizofrenię mimo różnych trudności nie przejawiała żadnych problemów psychicznych i rozwijała się prawidłowo. Garmezy jako pierwszy skupił się na analizie czynników chroniących, czyli prężności (Gąsior, Chodkiewicz, Cechowski, 2016). Wyniki niektórych badań wskazują, że osoby przejawiające wyższe nasilenie prężności w większym stopniu angażują się w relacje $\mathrm{z}$ innymi ludźmi, w tym $\mathrm{z}$ bliską osobą (Connor, 2006). Prężność psychiczna sprzyja także poczuciu bezpieczeństwa, satysfakcji z bliskości. Jest czynnikiem, który pozwala na stosowanie strategii radzenia sobie w sytuacjach kryzysowych, które są czymś naturalnym dla osób 
funkcjonujących w bliskiej relacji (Suwalska-Barancewicz, Malina, 2016). Wysoki poziom prężności sprzyja także tolerancji negatywnych emocji, niepowodzeń i konfliktów, co może prowadzić do poszerzenia wzajemnej relacji i budowania zaufania. Dzięki temu relacja może się również opierać na poczuciu bezpieczeństwa, wzajemnym szacunku i szczerości (Semmer, 2006).

Podsumowując dotychczasowe rozważania, należy stwierdzić, że środowisko rodzinne ma istotne znaczenie dla jakości funkcjonowania osób z rozpoznaniem schizofrenii. Charakter więzi i relacji pacjentów z rodzicami może stanowić czynnik wspomagający proces leczenia i zapobiegający nawrotom choroby (Bielańska, 2006). Ze względu na to, że część pacjentów $z$ rozpoznaniem schizofrenii ma problemy w relacjach interpersonalnych, które dotyczą między innymi niezdolności do odczuwania intymności i bliskości (Wright, 2008; Chrząstowski, 2012), problematyka analizowania relacji rodzinnych warta jest szczególnej uwagi. Uformowane na bazie wczesnych relacji z opiekunem doświadczenie własnej osoby oraz innych ludzi są istotne $\mathrm{w}$ procesie nawiązywania bliskich relacji w dorosłości (Bowlby, 2007). Powszechnie znane jest znaczenie stylu przywiązania wczesnodziecięcego dla późniejszych relacji jednostki w dorosłości (bezpieczne przywiązanie jest predyktorem satysfakcjonujących relacji), grupa pacjentów $\mathrm{z}$ rozpoznaniem schizofrenii stanowi jednak specyficzną grupę, w której dotychczas takie badania nie były realizowane. Nie bez znaczenia dla oceny jakości relacji z rodzicami jest prężność rozumiana jako przezwyciężanie trudności i powrót do równowagi po niekorzystnych zdarzeniach, która może wspomagać przeżywanie choroby i funkcjonowanie w społeczności. Dotychczasowe badania dotyczące prężności osób z rozpoznaniem schizofrenii wskazują, że osoby te cechują się niższym poziomem radzenia sobie w sytuacjach trudnych, niższą samooceną, silniejszą tendencją do unikania oraz niższym poziomem korzystania ze wsparcia społecznego (Horan i in., 2007). Założono zatem, że zasoby jednostki w postaci prężności mogą odgrywać rolę pośredniczącą między przywiązaniem do rodziców a jakością relacji z nimi w wymia- rze postrzeganego wsparcia, głębokości relacji oraz konfliktów. Zrozumienie roli prężności decydującej o możliwości jednostki w pokonywaniu wyzwań życiowych stwarza szansę bardziej wnikliwego postrzegania czynników wpływających na funkcjonowanie pacjentów w przebiegu choroby.

\section{PROBLEM I CEL BADAŃ}

W realizowanym projekcie podejmowany był problem znaczenia prężności osób z diagnozą schizofrenii dla jakości ich przywiązania i jakości relacji z rodzicami. Celem badania było zanalizowanie, czy poszczególne wymiary prężności (zasoby osobiste, rodzina i przyjaciele) oraz przywiązania (unikanie, niepokój) wiążą się z jakością relacji z rodzicami (postrzegane wsparcie, konflikt, głębokość relacji) osób z rozpoznaniem schizofrenii oraz wskazanie mediatorów wyznaczających jakość tych relacji. Zrozumienie znaczenia analizowanych zmiennych, ważnych dla pacjentów w przebiegu choroby, może być podstawą pogłębionej diagnostyki psychologicznej oraz terapeutycznej i stwarza szansę na bardziej korzystne funkcjonowanie intrapsychiczne $\mathrm{i}$ interpersonalne pacjentów.

\section{Badane zmienne i sposób ich pomiaru}

Na potrzeby realizacji badań uwzględniono następujące zmienne badawcze.

\section{Zmienna niezależna}

W realizowanych badaniach zmienną niezależną jest przywiązanie. Przywiązanie w ujęciu dymensjonalnym ma dwa wymiary: unikanie i niepokój. Wymiar unikania odnosi się do stopnia, w jakim jednostka stara się być autonomiczna względem swojego partnera w związku i braku zaufania do jego dobrej woli (np. „Rzadko martwię się o to, że bliska mi osoba mogłaby mnie zostawić"). Określa także, w jakim stopniu ludzie czują się niekomfortowo w relacjach $\mathrm{z}$ innymi, a w jakim bezpiecznie, zależąc od nich (Fraley, Waller, Brennan, 2000). Wymiar niepokoju natomiast oznacza stopień, $w$ jakim jednostka martwi się o dostępność i wsparcie 
partnera. Dotyczy także zakresu, w jakim ludzie czują się bezpiecznie w zależności od dostępności i reakcji partnera (np. „Boję się, że stracę miłość bliskiej mi osoby"). Osoby, które uzyskują niskie wyniki na obu wymiarach, określane są jako bezpiecznie przywiązane (Shaver, Mikulincer, Feeney, 2009). Operacjonalizacji poszczególnych poziomów zmiennej niezależnej dokonano na podstawie sumy punktów uzyskanych odpowiednio dla Skali Niepokój oraz Skali Unikanie, za pomocą Experiences in Close Relationships Revised autorstwa Chrisa Fraleya, Kelly Brennan oraz Neilsa Wallera, w polskiej wersji w adaptacji Cezarego Wiśniewskiego (2011). Wyniki analizy rzetelności polskiej wersji ECR-R wyniosły odpowiednio: dla Skali Niepokoju $\alpha$ Cronbacha $=.91$, dla Skali Unikania $\alpha$ Cronbacha $=.86$, co sugeruje wysoce satysfakcjonującą rzetelność narzędzia.

\section{Zmienna pośredniczaca}

$\mathrm{W}$ realizowanych badaniach zmienną mediującą (pośredniczącą) jest prężność ujmowana jako konstrukt odpowiedzialny za ,,potencjał do prezentowania zaradności przez użycie dostępnych wewnętrznych i zewnętrznych zasobów w odpowiedzi na zmiany kontekstu i zmiany rozwojowe" (Pooley, Cohen, 2010, s. 34). Prężność uznawana jest tu za grupę ochronnych czynników, które pomagają w utrzymaniu efektywności funkcjonowania i dobrostanu pomimo niesprzyjających warunków i obejmuje trzy aspekty: zasoby osobiste, wsparcie ze strony rodziny i wsparcie ze strony rówieśników. Do pomiaru prężności użyto polskiej adaptacji Lifespan Individual Resilience Scale(pl) [LIRS(pl)] pod roboczym tytułem Skala Osobistej Adaptacyjności, przeznaczonej do badania adolescentów i dorosłych. LIRS(pl) stanowi narzędzie samoopisowe składające się z 12 twierdzeń przyporządkowanych do trzech skal, odpowiadających trzem składowym prężności - zasobom osobistym (,Osiągam to, co postanowiłem/am zrobić"), wsparciu ze strony rodziny (,Moja rodzina jest dla mnie źródłem siły”) i ze strony rówieśników (,Czuję silną więź z przyjaciółmi”). Badany ustosunkowuje się do twierdzeń na 7-stopniowej skali (1 - zdecydo- wanie się nie zgadzam; 7 - zdecydowanie się zgadzam). Badanie przy użyciu narzędzia pozwala na uzyskanie ogólnego wyniku zarówno w zakresie prężności, jak i dla poszczególnych podskal. Rzetelność poszczególnych skal narzędzia mierzona współczynnikiem $\alpha$ Cronbacha jest satysfakcjonująca i wynosi dla zasobów osobistych (.85), dla wsparcia ze strony rodziny (.93) oraz dla wsparcia ze strony rówieśników (.94). Stabilność czasowa, szacowna przy użyciu współczynnika korelacji $r$ Pearsona, na podstawie dwóch pomiarów uzyskanych w odstępie czterech tygodni, ukształtowała się następująco: zasoby osobiste -.84 , wsparcie ze strony rodziny -.93 , wsparcie ze strony rówieśników - .90 (Malina, Pooley, Harms, 2016).

\section{Zmienna zależna}

Zmienną zależną $\mathrm{w}$ prezentowanych badaniach jest jakość relacji z rodzicami na wymiarze postrzeganego wsparcia, głębokości relacji oraz poziomu konfliktu interpersonalnego (Pierce, Sarason, Sarason, 1991). Wymiar głębokości relacji określa stopień, w jakim jednostki są zaangażowane w relację, i oceniają ją pozytywnie. Wymiar konfliktu wyznaczony jest stopniem, w jakim osoba odczuwa złość i uczucia ambiwalentne wobec partnera relacji. Natomiast wymiar postrzeganego wsparcia ujmowany jest jako stopień, w jakim można powoływać się na bliską osobę w celu otrzymania pomocy w różnych sytuacjach (Pierce, Sarason, Sarason, 1991). Metoda ta może być stosowana w badaniach dotyczących bliskich związków, zarówno romantycznych, małżeńskich, rodzinnych, jak i rówieśniczych.

Inwentarz jakości związku (polska adaptacja: Suwalska-Barancewicz, Izdebski, Liberska, 2015) to narzędzie samoopisowe składające się z 23 twierdzeń, do których osoba badana ustosunkowuje się na 4-stopniowej skali. Im wyższy wynik w danej skali, tym wyższe nasilenie właściwości mierzonych przez poszczególne wymiary. Skala Postrzeganego Wsparcia zbudowana jest $\mathrm{z}$ siedmiu twierdzeń (,W jakim stopniu możesz liczyć na to, że ta osoba wysłucha cię, gdy jesteś na kogoś zła/y?”), Skala Głębokości Relacji składa się z sześciu twierdzeń (,Jak znacząca jest ta relacja w twoim życiu?’), Skala 
Konfliktu zaś obejmuje 10 twierdzeń (,Jak bardzo ta osoba chce, abyś się zmieniła?"). Rzetelność poszczególnych skal narzędzia mierzona współczynnikiem $\alpha$ Cronbacha jest satysfakcjonująca i wynosi dla wsparcia (.79), dla konfliktu (.88) oraz dla głębokości relacji (.71).

\section{Charakterystyka osób badanych}

W badaniu wzięło udział 50 osób cierpiących na schizofrenię (średnia wieku 49.7; $S D=13.07$ ), z których $66 \%$ (33 osoby) stanowiły kobiety, a 34\% (17 osób) - mężczyźni. Kryterium włączenia do badań było rozpoznanie schizofrenii (F20-F29 według ICD-10), pełnoletność, świadoma zgoda na udział w badaniu, stan psychicz- ny w chwili badania pozwalający na zbieranie danych oraz stan remisji w zakresie ostrych objawów psychotycznych.

Większość badanych osób posiadała wykształcenie zasadnicze zawodowe - 54\%, gimnazjalne $22 \%$, a licencjat $16 \%$. Cztery osoby posiadały wykształcenie podstawowe lub niepełne podstawowe. Zdecydowana większość badanych $(67.35 \%)$ pochodziła z dużych miast (powyżej 100 tys. mieszkańców), 19.12\% kobiet mieszkało w mniejszych miastach, najmniej zaś - $13.53 \%$ kobiet - zamieszkiwało wieś. Połowa badanych osób trwała w związku małżeńskim (50\%), 34\% badanych było stanu wolnego, $10 \%$ osób było po rozwodzie, a $6 \%$ to wdowy/ wdowcy (tabela 1).

Tabela 1. Charakterystyka osób badanych: rozkład liczebności oraz rozkład procentowy zmiennych socjodemograficznych w badanej próbie

\begin{tabular}{|c|c|c|}
\hline Zmienna & Liczba & Procent \\
\hline \multicolumn{3}{|c|}{ Wykształcenie } \\
\hline Niepełne podstawowe & 2 & 4 \\
\hline Podstawowe & 2 & 4 \\
\hline Gimnazjalne & 11 & 22 \\
\hline Zasadnicze zawodowe & 27 & 54 \\
\hline Licencjat & 8 & 16 \\
\hline \multicolumn{3}{|c|}{ Miejsce zamieszkania } \\
\hline Miasto & 31 & 62 \\
\hline Miasteczko & 16 & 32 \\
\hline Wieś & 3 & 6 \\
\hline \multicolumn{3}{|c|}{ Stan cywilny } \\
\hline Kawaler/Panna & 17 & 34 \\
\hline Żonaty/Zamężna & 25 & 50 \\
\hline Rozwiedziony/Rozwiedziona & 5 & 10 \\
\hline Wdowiec/Wdowa & 3 & 6 \\
\hline \multicolumn{3}{|c|}{ Sytuacja mieszkaniowa } \\
\hline Mieszkam sam/sama & 12 & 24 \\
\hline Mieszkam z żoną/mężem & 17 & 34 \\
\hline Mieszkam z dziećmi/wnukami & 4 & 8 \\
\hline Mieszkam z żoną/mężem oraz dziećmi/wnukami & 4 & 8 \\
\hline Inne & 13 & 26 \\
\hline \multicolumn{3}{|c|}{ Sytuacja zawodowa } \\
\hline Rencista/emeryt & 24 & 48 \\
\hline Rencista/emeryt + dodatkowa praca & 5 & 10 \\
\hline Aktywny zawodowo & 21 & 42 \\
\hline
\end{tabular}


Przywiąanie pacjentów z rozpoznaniem schizofrenii a jakość ich relacji z rodzicami...

Tabela 2. Rozkład wyników (statystyki opisowe) badanych zmiennych

\begin{tabular}{|l|c|c|c|c|c|}
\hline \multirow{2}{*}{\multicolumn{1}{|c|}{ Zmienna }} & \multicolumn{5}{c|}{ Statystyki opisowe } \\
\cline { 2 - 6 } & $\mathbf{N}$ & Średnia & Minimum & Maksimum & Odch. stand. \\
\hline Satysfakcja z życia & 50 & 18.78 & 8.0 & 28.0 & 4.96 \\
\hline Postrzegane wsparcie & 50 & 19.10 & 7.0 & 26.0 & 5.02 \\
\hline Konflikt & 50 & 22.82 & 10.0 & 38.0 & 6.40 \\
\hline Głębokość relacji & 50 & 16.66 & 6.0 & 24.0 & 4.65 \\
\hline Rodzina & 50 & 20.80 & 4.0 & 28.0 & 5.95 \\
\hline Przyjaciele & 50 & 19.48 & 4.0 & 28.0 & 5.91 \\
\hline Zasoby osobiste & 50 & 18.86 & 6.0 & 28.0 & 4.58 \\
\hline Unikanie & 50 & 57.94 & 33.0 & 85.0 & 12.59 \\
\hline Niepokój & 50 & 52.20 & 16.0 & 76.0 & 14.66 \\
\hline
\end{tabular}

\section{Procedura}

Badania prowadzone były w okresie od 26 marca 2018 do 1 października 2018 roku w szpitalach, przychodniach oraz prywatnych gabinetach psychiatrycznych w Polsce. Osoby badane otrzymywały zestaw kwestionariuszy do wypełnienia. Wstępny kontakt następował poprzez lekarza lub innego pracownika opieki zdrowotnej znanego uczestnikowi. Wszystkie osoby zbierały się we wspólnej sali, każda otrzymywała zestaw kwestionariuszy. Po krótkim wyjaśnieniu procedury i celu badania uczestnicy rozpoczynali indywidualną pracę. Osoby badane zapoznano z zasadami dobrowolności i tajności badania. Przebadano 51 osób. Udział w badaniu był dobrowolny, a dobór osób - celowy. Uzyskano zgodę Uczelnianej Komisji ds. Etyki na realizację badań.

\section{WYNIKI BADAŃ}

W pierwszej kolejności dokonano analizy rozkładu zmiennych. Rozkład wyników w skalach jest zgodny z rozkładem normalnym, stąd też w celu weryfikacji przyjętych założeń użyto parametrycznych analiz.

W celu weryfikacji przyjętych w modelu badawczym zależności między zmiennymi wykorzystano współczynnik korelacji $r$ Pearsona oraz analizę regresji wielorakiej. Analizy statystyczne przeprowadzono $\mathrm{w}$ programie staty- stycznym Statistica 12.0. Analizę rozpoczęto od statystyk opisowych badanych zmiennych (tabela 2).

\section{Prężność osób z diagnozą schizofrenii a jakość relacji z rodzicami}

W pierwszej kolejności przystąpiono do określenia związku między poszczególnymi wymiarami prężności (rodzina, zasoby osobiste, przyjaciele) a jakością relacji osób (głębokość relacji, konflikt, postrzegane wsparcie). $\mathrm{W}$ tym celu posłużono się współczynnikiem korelacji $r$ Pearsona.

Wyniki wskazały na istotny związek między poszczególnymi wymiarami prężności a głębokością relacji $(r=.68 ; p<.0001)$. Im wyższy był poziom wsparcia płynącego od rodziny $(r=.74 ; p<.0001)$ i przyjaciół $(r=.47 ; p=$ $.001)$ oraz im wyższe były zasoby osobiste, tym wyższy był poziom głębokości bliskiej relacji, czyli zaangażowania $\mathrm{w}$ nią $(r=48 ; p<$ $.0001)$. Zachodzą również istotne statystycznie związki między poziomem postrzeganego przez pacjentów wsparcia a poziomem ich prężności osobistej. Wyższy poziom postrzeganego wsparcia wiązał się z wyższym poziomem prężności $(r=.68 ; p<.001)$. Okazało się, że im więcej wsparcia płynącego od bliskich $(r=.70, p<$ .001) doświadczali pacjenci, tym bardziej rodzina była dla nich źródłem siły, tym większą więź odczuwali względem przyjaciół $(r=.48$; 
Tabela 3. Związek między poszczególnymi wymiarami prężności a wymiarami jakości relacji

\begin{tabular}{|l|c|c|c|}
\hline \multirow{2}{*}{ Zmienna } & \multicolumn{2}{|c|}{$\begin{array}{c}\text { Współczynnik korelacji } \boldsymbol{r} \text { Pearsona, } \\
\boldsymbol{p}<\mathbf{. 0 5 0} \mathbf{N}=\mathbf{5 0}\end{array}$} \\
\cline { 2 - 4 } & Konflikt w relacji & Głębokość relacji & Postrzegane wsparcie \\
\hline Rodzina & .16 & .74 & .70 \\
\hline & $p=.280$ & $p<.0001$ & $p<.001$ \\
\hline Zasoby osobiste & -.080 & .48 & .53 \\
\hline & $p=.583$ & $p<.0001$ & $p<.001$ \\
\hline Przyjaciele & -.021 & .47 & .48 \\
\hline & $p=.883$ & $p=.001$ & $p<.0001$ \\
\hline Prężność & .031 & .68 & .68 \\
\hline & $p=.830$ & $p<.0001$ & $p<.0001$ \\
\hline
\end{tabular}

$p<.001)$ i tym wyższy był poziom ich zasobów osobistych $(r=.53 ; p<.001)$. Uzyskane współczynniki korelacji są wysokie. Nie odnotowano natomiast istotnych związków między poszczególnymi wymiarami prężności a poziomem konfliktów w relacji (tabela 3 ).

\section{Prężność osób z rozpoznaniem schizofrenii a przywiązanie do rodziców}

Kolejnym krokiem było wskazanie związków między poszczególnymi wymiarami prężności osób badanych a wymiarami ich przywiązania.

Wyniki wskazują na istotne związki pomiędzy wymiarami prężności a wymiarami przywiązania - niepokojem $(r=-.46 ; p=.001)$ i unikaniem $(r=-.41 ; p=.003)$. Okazało się, że im wyższy był poziom wsparcia płynącego od przyjaciół $(r=-.31 ; p=.030)$ i rodziny $(r=-.51 ; p<.0001)$ oraz im wyższy był poziom zasobów osobistych $(r=-.31 ; p=.030)$ niezbędnych do radzenia sobie z trudnościami, tym niższy był poziom niepokoju.

Z kolei im wyższy był poziom wsparcia płynącego od rodziny $(r=-.43 ; p=.002)$ oraz zasobów osobistych $(r=-.41 ; p=.003)$, tym niższy był poziom unikania przwiązaniowego. Brak istotnych związków między wsparciem przyjaciół a poziomem unikania $(r=-.21$; $p=.138)$ (tabela 4).

Tabela 4. Związek między poszczególnymi wymiarami prężności a wymiarami przywiązania osób badanych

\begin{tabular}{|c|c|c|}
\hline \multirow{2}{*}{ Zmienna } & \multicolumn{2}{|c|}{ Współczynnik korelacji $r$ Pearsona, $p<.0500, N=50$} \\
\hline & Niepokój & Unikanie \\
\hline \multirow[t]{2}{*}{ Prężność ogółem } & -.46 & -.41 \\
\hline & $p=.001$ & $\mathrm{p}=.003$ \\
\hline \multirow[t]{2}{*}{ Przyjaciele } & -.31 & -.2129 \\
\hline & $p=.030$ & $p=.138$ \\
\hline \multirow[t]{2}{*}{ Rodzina } & -.51 & -.43 \\
\hline & $p<.0001$ & $p=.002$ \\
\hline \multirow[t]{2}{*}{ Zasoby osobiste } & -.31 & -.41 \\
\hline & $p=.030$ & $p=.003$ \\
\hline
\end{tabular}


Tabela 5. Związek między wymiarami przywiązania osób badanych a wymiarami jakości relacji $\mathrm{z}$ rodzicami

\begin{tabular}{|c|c|c|c|}
\hline \multirow{2}{*}{ Zmienna } & \multicolumn{3}{|c|}{ Wspólczynnik korelacji $r$ Pearsona, $p<\mathbf{. 0 5 0 ,}, \mathrm{N}=\mathbf{5 0}$} \\
\hline & Postrzegane wsparcie & Konflikt & Glębokość relacji \\
\hline \multirow[t]{2}{*}{ Unikanie } & -.43 & .23 & -.44 \\
\hline & $p=.002$ & $p=.111$ & $p=.001$ \\
\hline \multirow[t]{2}{*}{ Niepokój } & -.58 & .37 & -.60 \\
\hline & $p<.0001$ & $p=.009$ & $P<.0001$ \\
\hline
\end{tabular}

\section{Przywiązanie osób z diagnozą schizofrenii a jakość ich relacji z rodzicami}

Następnie przystąpiono do określenia związków między wymiarami przywiązania a jakością relacji osób badanych. Posłużono się współczynnikiem korelacji $r$ Pearsona (tabela 5).

Zachodzą istotne związki między wymiarami przywiązania a jakością relacji z rodzicami osób badanych. Im wyższy jest poziom unikania przywiązaniowego, tym niższy poziom postrzeganego wsparcia $(r=-.43 ; p=$ $.002)$ i głębokości relacji $(r=-.44 ; p=.001)$. Nie ma istotnego związku między poziomem unikania a poziomem konfliktów w relacji $(r=.23 ; p=.111)$. Im wyższy był także poziom niepokoju, tym niższy poziom postrzeganego wsparcia $(r=-.58 ; p<.0001)$, konfliktu $(r=.38 ; p=.009)$ oraz zaangażowania $(r=-.60$; $p<.0001)$.

\section{Prężność jako mediator między wymiarami przywiązania osób badanych a jakością ich relacji z rodzicami}

Kolejne z prezentowanych analiz dotyczą określenia roli prężności jako mediatora między wymiarami przywiązania osób z diagnozą schizofrenii a jakością ich relacji z rodzicami. Aby tego dokonać, w pierwszej kolejno- ści należało sprawdzić istotność związków między:

- wymiarami przywiązania osób badanych (niepokój, unikanie) a prężnością;

- prężnością a jakością relacji z rodzicami (postrzegane wsparcie, głębokość, konflikt);

- wymiarami przywiązania osób badanych (niepokój, unikanie) a jakością relacji $\mathrm{z}$ rodzicami (postrzegane wsparcie, głębokość, konflikt).

Rozpoznanie istotności powyższych związków pozwoli włączyć prężność do analizy związku między wymiarami przywiązania osób z rozpoznaniem schizofrenii a jakością ich relacji z rodzicami. Jeśli w tym układzie zmienna prężność wykaże istotny spadek wskaźnika $\beta$ dla obliczonego związku między wymiarami więzi i jakością relacji, to możemy mówić o jej mediującym charakterze (C'; rysunek 1$)$.

Na podstawie uzyskanych $w$ trakcie badań wyników zaprezentowanych w tabelach 1-5 dokonano analizy prężności jako mediatora w związku między niepokojem przywiązaniowym a dwoma wymiarami jakości relacji (postrzegane wsparcie, głębokość relacji). Analizę mediacji przeprowadzono zgodnie $\mathrm{z}$ ujęciem zaproponowanym przez Reubena M. Barona i Davida A. Kenny'ego (1986) uzupełnionym o test Sobela (rysunek 2; Sobel, 1982). 
A

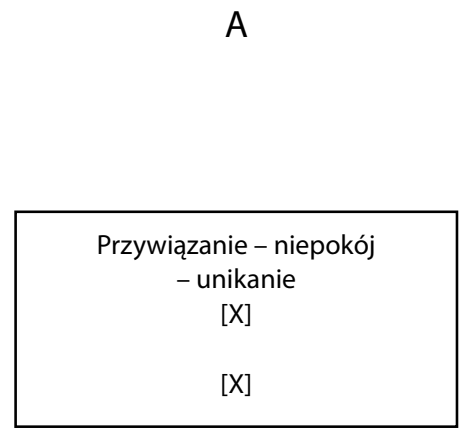

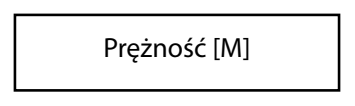

C

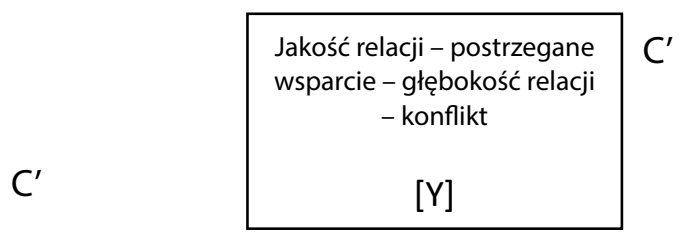

Rysunek 1. Schemat zależności między zmienną niezależną (wymiary przywiązania) a zmienną zależną (jakość relacji z rodzicami) za pośrednictwem zmiennej pośredniczącej (prężność) - poszukiwanego mediatora związku między zmienną X a zmienną Y. Podejście Barona i Kenny’ego (1986)

$$
\beta=-.46^{* * *}
$$

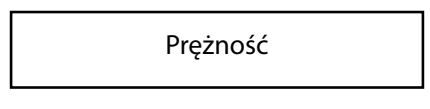

$$
\beta=.68^{* * *}
$$

$$
\beta=-.58^{* * *}
$$

Niepokój

$$
\beta=-.34^{* * *}
$$

Postrzegane wsparcie

Rysunek 2. Schemat mediacyjnej roli prężności pomiędzy niepokojem przywiązaniowym a postrzeganym wsparciem od rodziców $(* * * p<.001)$

\section{Prężność jako mediator między niepokojem przywiązaniowym osób z rozpoznaniem schizofrenii a wsparciem postrzeganym od rodziców}

W pierwszym etapie analiz mediacyjnych przyjęto następujące założenia: zmienna niezależna - niepokój przywiązaniowy; mediator - prężność; zmienna zależna - postrzegane wsparcie. Potwierdzono bezpośredni związek między zmienną niezależną - niepokojem przywiązaniowym, a mediatorem - prężnością (A). Zgodnie z przewidywaniami im niższy był niepokój przywiązaniowy, tym wyższym poziomem prężności charakteryzowały się osoby badane $(\beta=-.46 ; p<-.001)$. Testowany model regresji okazał się dobrze dopasowany do danych $\mathrm{F}(1,48)=12.54 ; p<.001 ; R^{2}=.19$. W tym przypadku należy podkreślić, że pomimo uzyskanych istotnych wyników w analizie regresji uzyskiwane współczynniki $R^{2}$ są stosunkowo niskie.
W drugim kroku analizy sprawdzono istotność związku między mediatorem (prężnością) a zmienną zależną (postrzeganym wsparciem, B). Ponownie relacja okazała się istotna: im wyższy był poziom prężności osób badanych, tym wyższy był również poziom postrzeganego przez nich wsparcia $\mathrm{w}$ relacji z rodzicami $(\beta=$ $.68 ; p<.001)$ - model był dobrze dopasowany do danych $F(1,48)=41.85 ; p<.001 ; R^{2}=.47$.

Trzeci krok analizy mediacyjnej polegał na określeniu związku między zmienną niezależną (niepokojem przywiązaniowym) a zmienną zależną (postrzeganym wsparciem, C). Okazało się, że im niższy był poziom niepokoju, tym wyższy był poziom postrzeganego wsparcia od rodziców $(\beta=-.58 ; p<.001)$. Testowany model regresji okazał się dobrze dopasowany do danych $F(1,48)=24.24 ; p<.001 ; R^{2}=.34$.

Ostatecznie, gdy w testowanym modelu uwzględniono zarówno zmienną niezależną oraz mediatora, rola zmiennej niezależnej w przewi- 


$$
\beta=-.46^{* * *}
$$

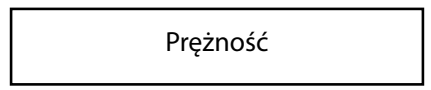

$\beta=.68^{* * *}$

$$
\beta=-.60^{* * *}
$$

Niepokój

$$
\beta=-.37^{* * *}
$$

Głębokość relacji

Rysunek 3. Schemat mediacyjnej roli prężności pomiędzy niepokojem przywiązaniowym a głębokością relacji z rodzicami $(* * * p<.001)$

dywaniu uległa osłabieniu $(\beta=-.34 ; p<.001)$, podczas gdy mediator pozostał $w$ istotnej relacji ze zmienną zależną $(\beta=.53 ; p<.001) F(2$, $47)=29.52 ; p<.001 ; R^{2}=.56$. Test Sobela wyniósł $-3.11(p<.001)$. Mamy tutaj do czynienia z częściową mediacją prężności, gdyż test Sobela jest istotny statystycznie i wartość $\beta \mathrm{w}$ regresji zmiennej niezależnej na zależną przy udziale mediatora ulega osłabieniu $(\beta=$ $-.58>\beta=-.34)$. Można, więc wywnioskować, że prężność jest istotnym mediatorem związku między niepokojem przywiązaniowym a postrzeganym przez osoby badane wsparciem: im niższy jest poziom niepokoju, tym wyższy poziom prężności osób badanych, a w efekcie wyższy poziom postrzeganego wsparcia od rodziców (rysunek 3).

\section{Prężność jako mediator między niepokojem przywiązaniowym osób z rozpoznaniem schizofrenii a głębokością relacji $\mathrm{z}$ rodzicami}

W pierwszym etapie analiz mediacyjnych przyjęto następujące założenia: zmienna niezależnaniepokój przywiązaniowy; mediator - prężność; zmienna zależna - głębokość relacji. Potwierdzono bezpośredni związek między zmienną niezależną (niepokojem przywiązaniowym) a mediatorem (prężnością, A). Zgodnie z przewidywaniami im niższy był niepokój przywiązaniowy, tym wyższym poziomem prężności charakteryzowały się osoby badane $(\beta=-.46$; $p<.001)$. Testowany model regresji okazał się dobrze dopasowany do danych $F(1,48)=12.54$; $p<.001 ; R^{2}=.19$. W tym przypadku należy podkreślić, iż pomimo uzyskanych istotnych wyników w analizie regresji uzyskiwane współczynniki $R^{2}$ są stosunkowo niskie.

$\mathrm{W}$ drugim kroku analizy sprawdzono istotność związku między mediatorem (prężnością) a zmienną zależną (głębokością relacji, B). Ponownie relacja okazała się istotna: im wyższy był poziom prężności osób badanych, tym wyższy również poziom głębokości relacji $\mathrm{z}$ rodzicami $(\beta=.68 ; p<.001)-$ model był dobrze dopasowany do danych $F(1,48)=41.24$; $p<.001 ; R^{2}=.45$.

Trzeci krok analizy mediacyjnej polegał na określeniu związku między zmienną niezależną (niepokojem przywiązaniowym) a zmienną zależną (głębokością relacji, C). Okazało się, że im niższy był poziom niepokoju, tym wyższy poziom zaangażowania $\mathrm{w}$ relację $\mathrm{z}$ rodzicami $(\beta=-.60 ; p<.001)$. Testowany model regresji okazał się dobrze dopasowany do danych $F(1,48)=27.60 ; p<.001 ; R^{2}=.35$.

Ostatecznie, gdy w testowanym modelu uwzględniono zarówno zmienną niezależną oraz mediator, rola zmiennej niezależnej w przewidywaniu uległa osłabieniu $(\beta=-.37 ; p<.001)$, podczas gdy mediator pozostał $\mathrm{w}$ istotnej relacji ze zmienną zależną $(\beta=.51 ; p<.001)$ $F(2,47)=31.38 ; p<.001, R^{2}=.55$. Test Sobela wyniósł $-3.04(p<.001)$. Mamy tutaj do czynienia z częściową mediacją prężności, gdyż test Sobela jest istotny statystycznie i wartość $\beta \mathrm{w}$ regresji zmiennej niezależnej na zależną przy udziale mediatora ulega osłabieniu $(\beta=$ $-.60>\beta=-.34)$. Można więc wywnioskować, że prężność jest istotnym mediatorem związku między niepokojem przywiązaniowym osób badanych a głębokością ich relacji z rodzicami: im niższy jest poziom niepokoju, tym 
wyższy poziom prężności osób badanych, a w efekcie wyższy poziom głębokości relacji $z$ rodzicami.

\section{DYSKUSJA}

Zrealizowane badania pozwoliły na potwierdzenie zależności pomiędzy poszczególnymi wymiarami prężności, wymiarami przywiązania osób z rozpoznaniem schizofrenii a jakościa ich relacji z rodzicami. Zarówno prężność, jak i wymiary przywiązania okazały się istotne dla jakości relacji osób z diagnozą schizofrenii i ich rodzicami. Zgodnie z założeniami popartymi literaturą przedmiotu wyższa prężność i ufność przywiązaniowa pozwalały przewidzieć lepszą jakość relacji z rodzicami. Rezultaty licznych badań podkreślają istotną rolę bezpiecznego przywiązania jako predyktora satysfakcjonujących, bliskich i ciepłych relacji, w przeciwieństwie do pozabezpiecznych stylów przywiązania (Kaźmierczak, Plopa, 2006; Liberska, Suwalska, 2011a, 2011b, 2011c). Bezpieczne przywiązanie stanowi też znaczący element satysfakcjonującego i pozytywnego współżycia, gdyż jednostki o tak ukształtowanym przywiązaniu wykazują wiele cech sprzyjających budowaniu relacji. Są empatyczne i otwarte, cechują się pozytywnym stylem komunikacji i tendencją do rozwiązywania problemów oraz sytuacji konfliktowych. $\mathrm{Z}$ łatwością nawiązują intymne relacje, nie boją się zależności, a siebie i innych postrzegają jako godnych miłości i wartościowych. Pozytywnymi cechami charakteryzują się również osoby o wysokim poziomie prężności: są bardziej otwarte wobec innych osób i pozytywnie nastawione do życia. Cechuje je także większa dojrzałość i stabilność emocjonalna, co może korzystnie wpływać na budowanie wartościowych relacji z innymi. Bezpieczne przywiązanie w połączeniu z wysokim poziomem prężności pomagają powrócić do równowagi psychicznej po niekorzystnych doświadczeniach (Ogińska-Bulik, Juczyński, 2008). Dostrzegamy istotną wartość aplikacyjną tych rezultatów, a mianowicie możliwość wykorzystania ich w procesie diagnostycznym i terapeutycznym. Brak ufności przywiązaniowej, a co za tym idzie - negatywny obraz siebie i/lub innych u pacjentów z rozpoznaniem schizofrenii - stwarza wyzwania dla pogłębionej pracy terapeutycznej w zakresie wzmacniania ufności przywiązaniowej, modyfikowania obrazu siebie i/lub innych w kierunku bardziej pozytywnym, co w konsekwencji może przynieść zdecydowanie lepsze (czy też bardziej korzystne) funkcjonowanie intrapsychiczne $\mathrm{i}$ interpersonalne $\mathrm{u}$ tych pacjentów.

Prężność odgrywała rolę mediatora pomiędzy niepokojem przywiązaniowym badanych a postrzeganym wsparciem i głębokością $\mathrm{w}$ relacji z rodzicami. Okazało się, że im niższy jest poziom niepokoju osób badanych, tym wyższy poziom postrzeganego przez nich wsparcia i głębokości relacji z rodzicami przy udziale wysokiej prężności. Można zatem wnioskować, że prężność pełni funkcję ochronną wobec trudności, z jakimi osoby z rozpoznaniem schizofrenii muszą się mierzyć w obliczu utrzymania pozytywnych relacji z innymi. Uzyskane rezultaty korespondują $\mathrm{z}$ wynikami badań opisanymi w literaturze przedmiotu, wskazującymi na znaczenie prężności jako czynnika buforującego wpływ negatywnych oddziaływań na dobrostan jednostki (Semmer, 2006; Ogińska-Bulik, 2014). Wskazują także na znaczenie działań terapeutycznych nakierowanych na rozwój różnorodnych strategii radzenia sobie, gdyż nie istnieje strategia uniwersalna, a szeroki repertuar strategii sprzyja skuteczności radzenia sobie w sytuacjach trudnych (Phillips $i$ in., 2009).

W realizowanych badaniach okazało się także, że nie występują istotne związki między poszczególnymi wymiarami prężności osób badanych a poziomem konfliktu $w$ relacji z rodzicami. Być może wynika to z faktu, że pacjenci z rozpoznaniem schizofrenii mają skłonność widzieć pozytywne aspekty relacji, zaprzeczając konfliktom, nieporozumieniom, rzadko mówią o rodzinie, a jeśli już, to wyraźnie idealizując ją w bardzo powierzchowny sposób (Jędrasik-Styła, Szkoda-Nowicka, 2011). Niewykluczone, że uzyskane wyniki mogą być rezultatem zniekształcającego wpływu zmiennej aprobaty społecznej. Być może badani próbowali pokazać się w lepszym świetle niż w rzeczywistości lub nadmiernie idealizowali bliską osobę. 
Antoni Kępiński swoją książkę pt. Schizofrenia dedykuje ,tym, którzy więcej czują i inaczej rozumieją i dlatego bardziej cierpią" (Kępiński, 1992, s. 6), zwracając uwagę na fenomen świata przeżyć osób z chorobą psychiczną. Te niezwykle indywidualne zjawiska życia psychicznego, często symboliczne, będące wyrazem bardzo głębokich lęków czy pragnień, są trudne do uchwycenia w przewidywalnym, konkretnym, niesymbolicznym języku statystyki, dlatego zdając sobie sprawę z ograniczeń tego opracowania, nie bagatelizujemy fenomenów świata przeżywanego osób badanych. Człowiek chory wraz ze swoim bogactwem przeżyć, poszukujący własnej drogi, zmagający się z samym sobą pokazuje świat, w którym przejawia się to, co najbardziej ludzkie, coś, co jest ponad mierzenie związków między analizowanymi zmiennymi.

Prezentowane badania, pomimo walorów naukowych, mają również pewne ograniczenia. Jedno z nich dotyczy ograniczonej możliwości generalizowania wyników badań na całą populację. O zawężonej możliwości generalizowania wyników przesądza celowy dobór osób do grupy badanej oraz niewielka liczba próby: były to osoby z rozpoznaniem schizofrenii posiadające kogoś bliskiego, na przykład rodzica. Przeprowadzenie badań w lepiej ustrukturyzowanej grupie, uwzględniającej większą liczbę osób znajdujących się w różnych formach związku oraz w różnych okresach rozwojowych, a także typ zdiagnozowanej schizofrenii mogłoby dostarczyć bardziej precyzyjnych informacji o naturze jakości życia osób badanych i złożoności jej uwarunkowań. Ponadto osoby, które wzięły udział w badaniach, w głównej mierze charakteryzowały się wykształceniem zawodowym, co mogło mieć znaczenie dla uzyskanych wyników. W realizacji przyszłych projektów badawczych warto więc zwrócić uwagę na większą dbałość o równoliczny dobór uczestników prowadzonych badań.

Kolejne ograniczenie dotyczy charakteru podjętych prac badawczych. Zaprezentowane badania opierały się na samoopisie badanego, a następnie - na podstawie uzyskanych za pomocą kwestionariuszy danych - wnioskowano o zachodzących zależnościach. Zastosowanie kwestionariuszy było podyktowane empiryczną tradycją badań w zakresie analizowanych zmiennych (prężności i przywiązania). Na przykład kwestionariusz ECR-R, jako metoda badania przywiązania, jest skalą powszechnie stosowaną na całym świecie, co daje możliwość porównywania wyników badań z innymi. Wyrażamy przekonanie, charakter przeprowadzonych przez nas wstępnie badań otwiera możliwość dalszej refleksji i formułowania pogłębionych pytań, na które odpowiedzi będzie można szukać z wykorzystaniem wywiadu i pogłębionej analizy narracyjno-fenomenologicznej.

Przedstawione badania w dużej mierze zostały zrealizowane w schemacie korelacyjnym. Pozwoliło to na wykrycie istotnych związków między analizowanymi zmiennymi oraz predykcję jednej zmiennej na podstawie drugiej. Badania korelacyjne uniemożliwiają jednak wnioskowanie przyczynowo-skutkowe (Sierau, Herzberg, 2012). W przyszłości cenne byłoby przeprowadzenie zarówno pomiarów jakościowych, jak i badań, które wskazałyby strukturę zależności przyczynowych oraz wpływ określonych zmiennych na jakość psychospołecznego funkcjonowania pacjentów $\mathrm{z}$ rozpoznaniem schizofrenii. Takie obserwacje pomogłyby lepiej zrozumieć położenie osób zmagających się $\mathrm{z}$ chorobą, a także ich rodzin.

W przyszłych badaniach w obszar eksploracji warto byłoby włączyć również inne zmienne, które mogłyby się okazać ważne z punktu widzenia jakości relacji w rodzinach $\mathrm{z}$ problemami psychicznymi. Literatura przedmiotu wskazuje bowiem, że istotny może być poziom samooceny, osobowość członków rodzin (Namysłowska, Siewierska, 1993; Ochojska, Radochoński, 1997), satysfakcja z życia, sposób radzenia sobie ze stresem czy wsparcie społeczne (Hazan, Shaver, 1987; Bartholomew, Horowitz, 1991; Cutrona, 1996; Dehle, Landers, 2005; Plopa, 2005; Cutrona i in., 2007). Warto również podkreślić znaczenie systematycznej edukacji pacjentów i ich rodzin w zakresie schizofrenii i jej leczenia. Dobra praktyka kliniczna umożliwia wskazanie rodzinom i pacjentom instytucji zapewniających wsparcie, pomaga w zdobywaniu rzetelnej wiedzy (Wright, 2008).

W tym miejscu chciałybyśmy podkreślić znaczenie uważności badacza na głębsze 
i bardziej wnikliwe rozumienie fenomenu świata przeżyć osób, u których rozpoznano schizofrenię. Odkrycie perspektywy, narracji tworzonych przez pacjentów na temat przeżyć i doświadczeń w chorobie pomaga w integrowaniu rozbitej tożsamości, może ułatwić powrót do funkcjonowania, a także w miarę umożliwia chorym dokonanie wglądu w siebie (Bielańska, 2006). Próba zrozumienia świata przeżywanego przez osoby z rozpoznaniem schizofrenii pozwala także uchronić przed uproszczonym i redukcjonistycznym spojrzeniem na sytuację tychże osób, z jednoczesną dbałością o godnościowy wymiar przeżywania choroby, co jest niezwykle istotne dla poczucia sensu życia i wartości każdego człowieka.

Zaprezentowane badania stanowią jedną z wielu możliwości eksploracji bliskich relacji rodzinnych i z pewnością nie wyczerpują szerokiego spektrum problematyki związanej $\mathrm{z}$ jakością funkcjonowania w obliczu chorób dotykających członków rodzinnego systemu. Uzyskane w trakcie badań wyniki mogą inspirować do formułowania kolejnych pytań, a co za tym idzie - stanowić punkt wyjścia dalszej eksploracji w obszarze jakości życia rodzinnego.

\section{PODZIĘKOWANIA}

Autorki dziękują dr Ewie Wojtynkiewicz za inspirujące myśli i życzliwe wsparcie w procesie opracowywania artykułu, a także za uwrażliwienie na fenomen świata przeżywanego przez osoby z rozpoznaniem schizofrenii.

\section{BIBLIOGRAFIA}

Ainsworth M.D.S., Blehar M.C., Waters E., Wall S.N. (1978), Patterns of Attachment: A Psychosocial Study of the Strange Situation and at Home. Hillsdale, NJ: Lawrence Erlbaum.

Alanen O.Y. (2000), Schizofrenia. Jej przyczyny i leczenie dostosowane do potrzeb, thum. J. Bomba. Warszawa: Instytut Psychiatrii i Neurologii.

Barbaro B. de (1999), Podejście systemowe. W: B. de Barbaro (red.), Schizofrenia w rodzinie, 15-46. Kraków: Wydawnictwo Uniwersytetu Jagiellońskiego.

Barbaro B. de, Ostoja-Zawadzka K., Cechnicki A. (2005), Możesz pomóc. Poradnik dla rodzin pacjentów chorych na schizofrenię i zaburzenia schizotypowe. Kraków: Wydawnictwo Uniwersytetu Jagiellońskiego.

Baron R.M., Kenny D.A. (1986), The Moderator-Mediator Variable Distinction in Socialpsychological Research: Conceptual, Strategic, and Statistical Considerations. Journal of Personality and Social Psychology, 51(6), 1173-1182.

Bartholomew K., Horowitz L.M. (1991), Attachment Styles Among Young Adults: A Test of Four-Category Model. Journal of Personality and Social Psychology, 61(2), 226-244.

Bielańska A. (2006), Psychoterapia indywidualna osób z diagnozą schizofrenii. Psychoterapia, 3(138), 75-86.

Bloch S., Hafner J., Harari E., Szmukler G. (1994), The Family in Clinical Psychiatry. Oxford: Oxford University Press.

Bowlby J. (2007), Przywiazanie, tłum. M. Polaszewska-Nicke. Warszawa:Wydawnictwo Naukowe PWN.

Brown G.W., Monc E.M., Carstairs G.M., Wing J.K. (1962), Influence of Family Life on the Cause of Schizophrenia. British Journal of Preventive and Social Medicine, 16, 55-68.

Charney D.S. (2004), Psychological Mechanisms of Resilience and Vulnerability: Implications for Successful Adaptation to Extreme Stress. American Journal of Psychiatry, 161, 195-216.

Chrząstowski S. (2012), Między nadmierną bliskością a odrzuceniem - rodziny osób z rozpoznaniem zaburzeń osobowości lub schizofrenii. W: B. Tryjarska (red.), Bliskość w rodzinie. Więzi w dzieciństwie a zaburzenia $w$ dorostości, 123-146. Warszawa:Wydawnictwo Naukowe Scholar.

Chrząstowski S., Zagdańska M. (2008), Porównanie nasilenia bliskości i intruzyjności w ocenie matek synów leczących się z powodu schizofrenii lub uzależnienia od narkotyków. Psychiatria Polska, 42, 217-249. 
Chudzikiewicz P. (2013), Wybrane aspekty doświadczania bliskich związków w kontekście schizofrenii. Psychiatria i Psychoterapia, 9(2), 3-16.

Connor K.M. (2006), Assessment of Resilience in the Aftermath of Trauma. Journal of Clinical Psychiatry, 67(2), 46-49.

Cutrona C.E. (1996), Social Support in Couples. Thousand Oaks, CA: Sage Publications.

Cutrona C.E., Shaffer P.A., Wesner K.A., Gardner K.A. (2007), Optimally Matching Support and Perceived Spousal Sensitivity. Journal of Family Psychology, 21, 754-758.

Czapiński J., Panek T. (red.), (2007), Diagnoza społeczna 2007. Warunki i jakość życia Polaków, www.diagnoza.com (dostęp: 29.11.2013).

Dehle C., Landers J.E. (2005), You Can't Always Get What You Want, But Can You Get What You Need? Personality Traits and Social Support in Marriage. Journal of Social and Clinical Psychology, 24(7), 1051-1076.

Doroszewicz K. (2008), Bliskie związki a jakość życia. Psychologia Jakości Życia, 7(1-2), 5-18.

Favaretto E., Torresani S., Zimmermann Ch. (2001), Further Results on the Reliability of Theparental Bonding Instruments (PBI) in an Italian Sample of Schizophrenic Patients and Their Parents. Journal of Clinical Psychology, 57, 119-129.

Florian V., Mikulincer M., Bucholtz I. (1995), Effect of Adult Attachment Style on the Perception and Search for Social Support. Journal of Psychology, 129, 665-676.

Fraley R.C., Waller N.G., Brennan K.A. (2000), An Item Response Theory Analysis of Self-Report Measures of Adult Attachment. Journal of Personality and Social Psychology, 78, 350-365.

Gąsior K., Chodkiewicz J., Cechowski W. (2016), Kwestionariusz oceny prężności (KOP-26). Konstrukcja i właściwości psychometryczne narzędzia. Polskie Forum Psychologiczne, 21(1), 76-92.

Hazan C., Shaver P. (1987), Romantic Love Conceptualized as an Attachment Process. Journal of Personality and Social Psychology, 52, 511-524.

Heszen I., Sęk H. (2007), Psychologia zdrowia. Warszawa: Wydawnictwo Naukowe PWN.

Hjemdal O. (2007), Measuring Protective Factors: The Development of Two Resilience Scales in Norway. Child and Adolescence Psychiatric Clinics of North America, 16, 303-321.

Horan W.P., Ventura J., Mintz J., Kopelowicz A., Wirshing D., Christian-Herman J., Foy D., Liberman P.R. (2007), Stress and Coping Responses to a Natural Disaster in People With Schizophrenia. Psychiatry Research, 151, 77-86.

Jędrasik-Styła M., Szkoda-Nowicka D. (2011), Deficyty funkcjonowania emocjonalnego pacjentów psychotycznych. Obserwacje kliniczne z psychoterapii grupowej. Psychoterapia, 4(159), 65-78.

Kaźmierczak M., Plopa M. (2006), Style przywiązaniowe partnerów a jakość komunikacji w małżeństwie. Psychologia Rozwojowa, 4, 115-126.

Kępiński A. (1992), Schizofrenia. Kraków: Sagittarius.

Liberska H., Suwalska D. (2011a), Attachment and Partnership in a Close Relationship. W: H. Liberska (red.), Relations in Marriage and Family: Genesis, Quality and Development, 31-51. Bydgoszcz: Wydawnictwo Uniwersytetu Kazimierza Wielkiego.

Liberska H., Suwalska D. (2011b), Quality of Close Relationship from the Viewpoint of Attachment Theory. W: H. Liberska (red.), Current Psychosocial Problems in Traditional and Novel Approaches, 59-78. Bydgoszcz:Wydawnictwo Uniwersytetu Kazimierza Wielkiego.

Liberska H., Suwalska D. (2011c), Znaczenie przywiązania dla funkcjonowania młodych dorosłych w związkach intymnych. W: H. Liberska, A. Malina (red. nauk.), Wybrane problemy wspótczesnych matżeństw i rodzin, 69-86. Warszawa: Difin.

Malina A., Pooley J.A., Harms C. (2016), Skala Osobistej Adaptacyjności - polska adaptacja Lifespan Individual Resilience Scale. Przegląd Psychologiczny, 59(4), 435-450.

Mikulincer M., Florian V. (1997), Are Emotional and Instrumental Supportive Interactions Beneficial in Times of Stress? The impact of attachment style. Anxiety, Stress and Coping, 10, 109-127.

Mikulincer M., Shaver P.R. (2007), Attachment in Adulthood: Structure, Dynamics, and Change. New YorkLondon: The Guilford Press.

Namysłowska I., Siewierska A. (1993), Miejsce terapii rodzin w leczeniu schizofrenii. Postepy Psychiatrii i Neurologii, 2, 351-357. 
Ochojska D., Radochoński M. (1997), Choroba w rodzinie. Style zmagania się z sytuacją trudną. Problemy Rodziny, 6, 19-22.

Ogińska-Bulik N. (2014), Prężność psychiczna a zadowolenie z życia osób uzależnionych od alkoholu. Alcoholism and Drug Addiction, 24(7), 319-324.

Ogińska-Bulik N., Juczyński Z. (2008), Osobowość. Stres a zdrowie. Warszawa: Difin.

Parker G. (1990), Parental Bonding Instrument. A decade of Research. Social Psychiatry and Psychiatric Epidemiology, 25, 281-282.

Perlman D. (2007), The Best Times, The Worst Times: The Place of Close Relationships in Psychology and Our Daily Lives. Canadian Psychology, 48(1), 7-18.

Phillips L.J., Francey S.M., Edwards J., McMurray N. (2009), Strategies Used By Psychotic Individuals to Cope with Life Stress and Symptoms of Illness: A Systematic Review. Anxiety Stress Coping, 22(4), 371-410.

Pierce G.R., Sarason I.G., Sarason B.R. (1991), General and Relationship-Based Perceptions of Social Support: Are Two Construct Better Than One? Journal of Personality and Social Psychology, 61(6), 1018-1039.

Plopa M. (2005), Więzi w malzeństwie i rodzinie. Metody badań. Kraków: Impuls.

Pooley J.A., Cohen L. (2010), Resilience: A Definition in Context. Australian Community Psychologist, 22(1), $30-37$.

Pooley J.A., Cohen L., Connor M. (2010), Community Resilience: A Study of Communities Facing Impending Natural Disasters. Berlin: Lambert Academic Publishing.

Ryś M. (1999), Psychologia matzeństwa w zarysie. Warszawa: Centrum Metodyczne Pomocy Psychologiczno-Pedagogicznej Ministerstwa Edukacji Narodowej.

Semmer N. (2006), Personality, Stress and Coping. W: M. Vollrath (red.), Handbook of Personality and Health, 73-113. Chichester: Wiley.

Sęk H., Steuden S. (2016), Psychologia schizofrenii. W: L. Cierpiałkowska, H. Sęk (red.), Psychologia kliniczna, 555-573. Warszawa: Wydawnictwo Naukowe PWN.

Shaver P.R., Mikulincer M., Feeney B.C. (2009), What's Love Got to Do with It? Insecurity and Anger in Attachment Relationships. Virginia Journal of Social Policy \& the Law, 16(2), 491-513.

Sierau S., Herzberg P.Y. (2012), Conflict Resolution as a Dyadic Mediator: Considering the Partner Perspective on Conflict Resolution. European Journal of Personality, 26, 221-232.

Sobel M.E. (1982), Asymptotic Confidence Intervals for Indirect Effects in Structural Equation Models. W: S. Leinhart (red.), Sociological Methodology, 290-312. San Francisco: Jossey-Bass.

Stierlin H., Rucker-Embden I., Wetzel N., Wirsching M. (1999), Pierwszy wywiad zrodzina, thum. M. Kacmajor, E. Zubrzycka. Gdańsk: Gdańskie Wydawnictwo Psychologiczne.

Suwalska-Barancewicz D., Malina A. (2016), Prężność partnerów, strategie radzenia sobie w sytuacji trudnej a jakość ich związku. Polskie Forum Psychologiczne, 21(3), 322-340.

Suwalska-Barancewicz D., Izdebski P., Liberska H. (2015), The Quality of Relationships Inventory - polska adaptacja. Psychologia Rozwojowa, 20(1), 91-105.

Świętochowski W. (2014), Choroba przewlekła w systemie rodziny. W: H. Liberska, I. Janicka (red.), Psychologia rodziny, 387-410. Warszawa: Wydawnictwo Naukowe PWN.

Uchino B.N., Cacioppo J.T., Kiecold-Glazer J.K. (1996), The Relationship Between Social Support and Psychological Process: A Review with Emphasis on Underlying Mechanism and Implications for Health. Psychological Bulletin, 119, 488-531.

Uznańska K., Czabała J.C. (2004), Cechy osobowości a związki małżeńskie osób chorych na schizofrenię. Psychiatria Polska, 38(3), 409-419.

Waters E., Cummings E.M. (2000), A Secure Base from Which to Explore Close Relationships. Child Development, 71(1), 164-172.

Wiśniewski C. (2011), Przywiązanie a kontrola emocjonalna. Niepublikowana praca magisterska.

Wright P. (2008), Schizofrenia i inne zaburzenia psychotyczne. W: P. Wright, J. Stern, M. Phelan (red.), Psychiatria. Sedno, T. 1, thum. D. Bibułowicz i in., 257-286. Wrocław: Elsevier Urban \& Partner. 